\title{
Student Centred Learning: Translating \\ Trans-National Commitments into \\ Institutional Realities. The Romanian \\ Experience
}

\author{
Liviu Matei, Cezar Mihai Hâj and Daniela Alexe
}

Keywords Student-centred learning - Bologna process - Teaching and learning • Learning outcomes $\cdot$ ECTS system $\cdot$ Teaching quality $\cdot$ Innovative teaching methods

\section{Introduction}

\subsection{Theoretical Framework}

The Bologna Process was launched in 1999 as a voluntary inter-governmental initiative aiming at the formation of the European Higher Education Area (EHEA). "Bologna" is both a transformation process of European higher education systems and a political institution (Reinalda 2008). As many researchers propose, the process can be viewed as a consequence of European integration, or as a proactive attempt of Europeanization of higher education systems. "Europeanization" in this context means more than just the expansion, or evolution of the European Union (Trodal 2002; Corbett 2003; Corbett 2005; Corbett 2006; Veiga 2005; Adelman 2009; Damme 2009). Pursuing a European integration agenda, the Bologna Process started as an intergovernmental initiative independent from the

\footnotetext{
L. Matei $(\triangle)$

Department of Public Policy, Central European University, Budapest, Hungary

e-mail: mateil@ceu.hu

C.M. Hâj · D. Alexe

Executive Agency for Higher Education, Research, Development and Innovation Funding (UEFISCDI), Bucharest, Romania

e-mail: cezar.haj@uefiscdi.ro

D. Alexe

e-mail: daniela.alexe@uefiscdi.ro

C.M. Hâj

National University of Political Studies and Public Administration (SNSPA),

Bucharest, Romania

(C) The Author(s) 2015

A. Curaj et al. (eds.), Higher Education Reforms in Romania,

DOI 10.1007/978-3-319-08054-3_6
} 
European Union (it was not launched and it is not controlled by the EU, although the EU Commission is a formal member). Several countries that were not members of the Union signed the Bologna Declaration from the very beginning, and other non-EU countries quickly came to the conclusion that being inside the Bologna circle was more beneficial than being left out, which determined them to join later (Haskel 2009). The special nature of the Bologna Process, involving the participation of both EU and non-EU countries within the geographical area of the European Cultural Convention (47 at present altogether), and of the European Commission, shaped the evolvement of the overall process and influenced the actual course of the envisaged reforms in higher education.

Far from having a homogenous or linear impact in all signatory countries, the Bologna Process, as characterised above, had a varied but noticeable influence across European higher education systems. Part of this influence was possible given the fact that Bologna Process brought about new concepts, a new vocabulary, and also new policies, tools, and practices in higher education. The concept of SCL and associated policies and practices are an important illustration of this process, at least for the case of some countries in the European Higher Education Area.

The original development of the SCL concept (ESU 2010), is credited to Hayward (as early as 1905) and to Dewey's work (including posthumous publications after 1956). Carl Rogers expanded this approach into a theory of education in the 1980s. This approach to learning has also been associated with the work of Piaget (developmental learning) and Malcolm Knowles (self-directed learning). A review of the SCL literature resulted in the following characterisation of the concept: the reliance on "active rather than passive learning", an emphasis on "deep learning and understanding", "increased responsibility and accountability"of the student, encouraging an "increased sense of autonomy" for the learner, an "interdependence between teacher and learner", "mutual respect within the learner-teacher "relationship and a "reflexive approach to the teaching and learning process" on the part of both the teacher and the learner (LEA 2003).

SCL takes a broadly constructivist view as a theory of learning, built on the idea that learners must construct and reconstruct knowledge in order to learn effectively, with learning being most effective when, as part of an activity, the learner experiences constructing a meaningful result. Consequently, adequate teaching methods become an important part of this approach.

SCL is also connected to transformative learning, which takes into consideration a process of qualitative change in the learner, on an on-going basis, focusing on enhancing and empowering the learner and developing her/his critical thinking ability.

Efforts have been made, as part of the Bologna Process, to include SCL in the broad program of reforms of higher education. In turn, the on-going process of learner transformation and empowerment can be analysed within the Bologna Process, inter alia, with the help of other key "Bologna concepts", such as, Learning Outcomes and the ECTS. 


\subsection{General Overview}

\subsubsection{The Bologna Process in the European Context}

The chief objective of the Bologna Process, the creation of a European Higher Education Area (EHEA), was to ensure more comparable, compatible and coherent systems of higher education in Europe. The main "action lines" of the Process are reflected in the directions which, throughout the years, have represented official and explicit priorities of the Bologna Process. The list of action lines includes besides other areas such as social dimension, lifelong learning, recognition of prior learning, internationalization of education, mobility, quality assurance etc., a Student Centred Learning dimension as well.

Student-centred learning is rather a new concept and it has not been directly addressed at the beginning of the Bologna Process. Moreover, when SCL started being considered, it was not a separate action line, but rather regarded as a "transversal concept". With the adoption of the Leuven Communiqué, an increased emphasis has been placed on teaching and learning in higher education institutions, on curriculum reorganization, and on the introduction of learning outcomes as an instrument in the teaching process. In turn, this new focus brought about more attention to SCL: student-centred education involves focusing on the learner, new approaches to teaching and learning, effective support and guidance structures. The curriculum reform is a continuous process that will lead to high quality education trends, flexible and focused on the individual (Communiqué of the meeting of European Ministers in charge of Higher Education 2009). The Leuven Communiqué talks about the impact of student-centred education on the development of student skills, which are considered necessary for a labour market that is in constant change, and also for the integration of students into society as active and responsible citizens. The most recent Bologna Ministerial Communiqué adopted in Bucharest established the stimulation of student-centred learning and of innovative learning methods as priorities for the next period in the European Higher Education Area (Communiqué of the meeting of European Ministers in charge of Higher Education 2012).

The present article considers the existence of a wide range of definitions given to the SCL. However, it specifically looks at the implementation of SCL in Romania using as a proxy the meaning of the concept as expressed in the Bologna commitments formulated in the Ministerial Communiqués. In fact, for better or worse, the introduction of SCL in Romania is strictly related to the Bologna Process, with no other policy or conceptual references. In this regard, we have analysed the successive official Communiqués adopted during the Bologna Process in order to extract and resume the main commitments regarding SCL. They can be summarized as follows:

- The institutions should strike a connection between study credits, learning outcomes and student workload and include learning outcomes acquisition in the assessment procedures (Bucharest 2012); 
- The commitment must be reiterated to promote student-centred education characterized by innovative teaching methods and by the involvement of students as active partners in their own education (Bucharest 2012);

- Higher education institutions should pay attention to improving the quality of teaching within the study programmes at all levels (Leuven 2009);

- Student centred education involves focusing on the learner, new approaches to teaching and learning, effective support and guidance structures. The curriculum reform is a continuous process that will lead to high quality education trends, flexible and focused on the individual (Leuven 2009).

Based on this summary, this article will try to look at how higher education institutions in Romania, as a signatory country of these communiqués, understand the concept of SCL through ECTS, learning outcomes, student workload, innovative teaching methods and quality of teaching.

\subsubsection{The Bologna Process in Romania}

Romania signed the Bologna Declaration in 1999, at the very beginning of the Process. Since then, Romania has voluntarily taken steps to align its higher education policies to the objectives and the policies promoted by Bologna. As a consequence, the higher education system in Romania has undergone a series of fundamental reforms, by adjusting legal procedures, promoting new national public policies, creating new institutional structures, regulations and guidelines for universities (UEFISCDI 2013).

The Bologna Process has been implemented in Romania in a context characterized first of all by one of the biggest increases in student population in Europe until 2008 (the number of bachelor students increased more than five times from 1990 to 2008). However, after 2008, student numbers began to rapidly decline. One can see the same trend in the evolution of the number of higher education institutions (both public and private): this number increased almost three times from 1990 to 2003, and from 2003 it started to decline. On the legal side, a new framework was adopted between 2004 and 2006 to allow for the implementation of the Bologna Process in Romanian universities (mainly linked to the introduction of the three cycle system, the ECTS, diploma supplement implementation and creation of new quality assurance arrangements).

The national institutions responsible with implementing the Bologna Process in Romania were: the Ministry of National Education (MEN), aided by its consultative bodies: the National Council for Higher Education Funding (CNFIS); the National Council for Research in Higher Education (CNCSIS - abolished with the adoption of the new Law of Education No. 1/2011); the Romanian Agency for Quality Assurance (ARACIS); the National Agency for Qualifications (ANC); the Executive Agency for Higher Education, Research, Development and Innovation Funding (UEFISCDI) and the Romanian Rectors' Conference (CNR), in close interaction with higher education institutions, national student federations and teachers' unions. 
Between 2010 and 2012, in particular, Romania played an active role within the Bologna Process by organizing the 2012 Bologna Ministerial Conference, the Third Bologna Policy Forum, and by hosting the Bologna Follow-Up Group Secretariat (the Secretariat developed for the first time during this period a permanent EHEA website and a very useful online archive of Bologna policy documents).

\subsection{The Context of This Article}

The article is based on the work carried out by the authors within the project "Higher Education Evidence Based Policy Making: a necessary premise for progress in Romania" implemented by the Executive Agency for Higher Education, Innovation and Development Funding (UEFISCDI). The project undertook to systematically identify all commitments assumed by Romania within the Bologna Process and then to analyse their implementation, including those regarding SCL. Methodologically, the authors relied on extensive desk research that included gathering and analysing information about the national legal framework, gathering and analysing official documents of international and national institutions, as well as perception studies and research articles in the field of SCL. The most important legislative sources relevant for the current analysis were the Law of Education no.1/ (2011) and the ARACIS methodology for institutional quality assurance assessments. In addition, seven focus groups were organized within the above mentioned project, with the participation of former and present Romanian representatives within various Bologna Process structures (BFUG, Working Groups, Networks), representatives of the national institutions that deal with the Bologna Process Implementation (ARACIS, CNFIS, ANPCDEFP, MEN), national experts and former representatives of the Romanian Bologna Secretariat (2010-2012).

The research about the implementation of the Bologna commitments in Romania was a ground-breaking effort (there is very little similar research in any other country of the European higher education area). When gathering information about this topic, regarding implementation aspects rather than just policy blueprints and generic frameworks, one realises that relevant data regarding the Romanian higher education system, both at system and institutional level, is hard to come by. We have been able, fortunately, to access two very useful and somewhat unexpected sources of information/data, which are directly relevant for the current analysis. One of these sources is the European University Association's institutional evaluation of Romanian universities, which includes a first and second wave of institutional reports (2012-2013). The second one consists of the institutional strategies made public on their official websites by the Romanian universities.

The European University Association (EUA), through its Institutional Evaluation Programme (IEP), evaluated a large section of public Romanian universities: 41 public institutions were evaluated in 2012-2013. For the article, an analysis of 27 institutional reports was conducted. The analysed reports included 27 universities from two of the three university categories (research intensive universities and 
teaching and research universities), according to the university classification in Romania. From the total number of available reports in the above mentioned two categories, military and arts universities' reports, were excluded due to their very specific characteristics which are not relevant for the general picture. Educationintensive universities, the third category in the Romanian context, were not included in the analysis, as the IEP reports were not yet public for all of them and the review process is still on-going.

Another source of information used in the analysis of the implementation on Bologna commitments with regard to SCL in Romania were the "strategic frameworks of universities", mainly for the period 2013-2016. Such strategic framework documents (published as "strategic plans", "development strategies", "managerial contracts", "managerial programmes", "strategies" etc.) were elaborated and adopted in the context of the election for the university leadership and Senate membership organised in 2012-2013. Thirty-three public universities' strategies were analysed. The strategic documents of the rest of sample institutions could not be found on their official web sites.

\section{SCL in Romanian Higher Education System}

\subsection{Approaches to Student Centred Learning-from the National to the Institutional Level}

In the process of mapping the national legislation on education, we found that a main chapter of the Law of education no. 1/(2011) is entitled the "student centred university". This chapter includes chiefly provisions regarding student rights at national and institutional level, student admission, data collection, financing, student services or student representation. There are no explicit mentions regarding SCL, but the chapter provides for the adoption of a "Student Rights and Obligations Code" (The Student Statute), in which further details are regulated. The Student Statute specifically describes the students' right to "benefit from SCL for personal development, integration into society and the development of skills to gain initial employment, to maintain it, and to be able to move within the labour market".

We have analysed the above mentioned reports from 27 public universities considering the Bologna commitments regarding SCL. We focused on the general institutional approach to student centred learning and on specific elements of SCL, namely: the situation regarding the implementation of learning outcomes at institutional level, the links between the ECTS system and the students' workload, the existence of innovative teaching methods and the approaches to enhancing quality of teaching.

As a general remark, in 11 institutional reports there is a mention regarding the limited awareness or partial understanding of the Bologna principles by the academic communities, referring either to Bologna policies in general, or to certain 
commitments regarding SCL, ECTS, learning outcomes, or the European Standards and Guidelines for Quality Assurance in Higher Education (ESG). These remarks appear to indicate that even if the Bologna action lines have been implemented at national level, not all the subsequent policies are internalised at institutional level. Oftentimes they are implemented only in a formal way, simply as a consequence of national regulations.

Analysing the 27 institutional reports regarding the general approach of universities to SCL, four groups could be identified:

1. Universities with not even a single reference to SCL in their reports. Even though teaching was included in the IEP evaluation guidelines, five reports were identified in which no reference to SCL was made.

2. Universities with no institutional approach to SCL. In nine cases, the reports mention that there is no institutional approach to SCL. The reports either did not identify a SCL framework, or the evaluators did not find real evidence of SCL implementation. In these cases the main recommendation formulated by the external review panels was for the respective institutions to start by adopting a SCL philosophy. The recommendation is detailed in some reports by formulating more specific guidelines, such as: reduce behind-the-desk teaching in favour of a more practical, hands-on approach; accurately use ECTS, as both a measure for student workload and learning outcomes; design a more flexible curriculum including optional courses to allow for individualised learning pathways; develop a student-centred curriculum; information provisions for students should contain an explanation of the overall aims and purposes of the courses; adopt clear guidelines on written and project work; adopt clear principles on performance assessment, marking and feedback to students; adopt a learning outcomes approach.

3. Universities with some elements of SCL. The third category, in which six universities are included, can be described as: "some elements of a SCL are being implemented, but further efforts need to be done". The recommendations included in the external reports can be understood as referring to the so-called second level of SCL implementation - promoting active learning among students and placing a greater emphasis on the development of transversal competences and skills.

4. Universities in which clear commitments exist and efforts are made towards SCL. Seven institutions could be included in this category. The conclusions of the evaluations mention in these cases that "departments have made sustained efforts to develop student centred learning", or "commitments have been made to a student-centred approach and to the use of a variety of teaching methods to ensure high standards of student learning". A good-practice example was mentioned: one university prepared written guidelines for teachers regarding SCL.

Considering that in 15 universities there was no evidence of SCL or there were only some elements in place, while in seven universities serious efforts were identified, one particular conclusion regarding SCL stood up in the reports. This 
conclusion might be relevant for the higher education system in Romania in general. It states that "it is not sure to what extent the concept of student-centred learning is clearly understood and perceived in Romania and to what extent it is a constituent part of the current reform". The review panels have identified in only two of the universities under review the existence of a strategic approach to SCL. For ten institutions the review panels recommended that a teaching and learning strategy should be developed to further the implementation of SCL principles.

\subsubsection{Strategic Institutional Approaches to SCL-A View to the Future}

Taking into account Romania's commitments regarding SCL within the Bologna Process, we will analyse in what follows how Romanian higher education institutions refer to SCL in their strategic documents and how they understand and operationalize the concept, encompassing, inter alia, ECTS, learning outcomes, student workload, innovative teaching methods, and quality of teaching.

We have analysed the SCL plans and commitments for the future, as reflected in the university strategies for the immediately next period (mainly 2013-2016).

The first finding is that 20 out of 33 universities have clear statements (including general or specific objectives) regarding the implementation of SCL. For the remaining universities, no reference to SCL was found for the near future.

A second finding is that in some cases SCL seems to be defined, rather paradoxically, through a "teacher-centred" approach. This is reflected, for example, in the inclusion in the university strategy for the next period of the objective of "enhancing the activities of information transfer in the context of SCL". This approach was also noticed in one of the IEP evaluation reports, in which the Romanian HE system as a whole is characterised by a continuing focus on information transfer (belonging to the traditional methods of teaching), rather than on the learning process.

Going further, for the case of the 20 universities with clear statements on SCL, we have analysed how the SCL commitments have been operationalized within institutional strategies. We tried to identify if any clear measures were envisaged, subscribed to the concept of SCL as defined within the Bologna Process. We found that that there is quite a diverse range of measures within the universities, as described below. In three cases, the only measure envisaged is a study to be undertaken, or proposal to be developed by an internal university unit or structure of the way in which SCL could or will be operationalized within the institution.

The most frequently mentioned measure in these university strategic documents is related to changes in the teaching methods, referring either to the adoption of new, innovative teaching methods, or to adaptation of the existing teaching methods to the SCL concept (six cases). The second most common measure is the involvement of students in research activities (five cases). The third most common measures (with four appearances) refer to enhancing quality assurance procedures for teaching processes, and to the adaptation of curriculum to the socio-economic needs of the community. Other measures mentioned are: involving students in the 
course assessment; the development of a mentoring system in order to enhance the collaboration between teachers and students; consistently defining, using and assessing learning outcomes within the teaching and learning processes; enhancing the practical experience of students; the active involvement of students in the academic process; reforming the curriculum; developing social services; encouraging students' academic performance; the development of soft skills and others.

Comparing the Bologna proposed approach to SCL with the measures proposed in the strategic frameworks of these Romanian universities that do include SCL in their strategic planning, we can conclude that even though in several universities some Bologna SCL commitments are indeed reflected in institutional strategies, the majority of institutions have their own understanding of SCL. Another general remark is that SCL remains a concept under which each university "uploads" different domestic objectives that have nothing to do with what is broadly understood as SCL in the European context (for example, employing students in the university or planning activities for alumni). It appears that, similar to other loose concepts diffused by European-level (Bologna) policy processes, such as like lifelong learning or the social dimension of education, in Romania SCL became an umbrella concept under which institutions can push their own specific domestic agendas, while retaining the legitimacy of European reform models.

\subsection{The Link Between Learning Outcomes (LO) and ECTS in the Context of SCL}

According to Ecclestone, learning outcomes can be defined as being something that students can do now at the end of a unit of learning (e.g. course) and they could not do previously (Ecclestone 1995). Thus, learning outcomes can be regarded as changes within a person as a result of a learning experience. In order to be able to use learning outcomes within higher education, it is important to link them with assessment: assessment must be both possible and appropriate. The desired learning outcomes of higher education courses must be therefore not only relevant, they must also be clearly stated and assessable (Watson 2002).

In Romania, the Law of Education no. 1/(2011) defines learning outcomes as: what a person understands, knows and is capable to do after finishing a learning process; they are expressed through knowledge, abilities and competences, and are acquired through different formal, non-formal and informal learning experiences. The law also defines the assessment, validation, transfer, recognition and certification of learning outcomes. There is no link made in the Law between learning outcomes and the ECTS system.

According to the Methodology of Implementation of the National Qualifications Framework in Higher Education (NQF), the grids introduced in the National Qualification Framework for Higher Education (CNCIS) for each study programme include the description of the programme in terms of learning outcomes. The first 
grid makes reference to professional skills, transversal abilities, knowledge and skills, while the second connects the respective skills with the allocation of study credits for each skill and per field of study.

Out of 27 evaluation reports prepared for the IEP, in the case of seven universities there are no references regarding the learning outcomes. Based on these reports, the main conclusion is that learning outcomes are indeed formally defined at institutional level (mainly due to the fact that they are legally required), but they are not fully implemented, and not in a coherent and integrated way across the institutions, in accordance with the Bologna Process or with the ECTS Users' Guide. This conclusion is also supported by other main findings from 18 universities: "learning outcomes were mainly used to satisfy returns and specifications required by ARACIS, rather than as effective tools for programme delivery"; "while emphasis is placed on setting objectives and identifying competences, knowledge, and skills, this still falls short of a learning outcomes approach".

The findings of the reports, where mentions were found, lead to one main conclusion regarding the assessment of learning outcomes (although expressed in various ways): assessment procedures are not aligned with learning outcomes.

In the majority of cases, the IEP external reports recommendations in the area of learning outcomes refer basically to the need to introduce and develop a learning outcome approach at institutional level, bearing in mind the wide span of possible educational objectives.

Two particular issues were signalled in the EUA IEP reports as being present in the majority of Romanian universities: the need for skills development and also for developing the practical experience of students. In this regard, in 15 cases the reports state the lack of or the insufficient opportunities for student internships. The Romanian legislation mentions the obligation for practical experience to be embedded in the curriculum, but universities are not always able to facilitate internships for all the students (often they offer a limited number of internships and the rest of students are supposed to find internships by themselves). In only six cases there are recommendations for providing "soft skills" development to students, because the dominant tendency is to develop and assess knowledge and specialised skills at the expense of the so-called transversal or soft skills (some examples are mentioned in the reports, for example public speaking, presentation skills, writing academic papers, team work and others).

In the ECTS system, the formulation of learning outcomes is meant to be the basis for how the workload is estimated and hence for credit allocation. When those responsible for designing educational programmes establish the qualification profile and the expected learning outcomes of the programme and its components, it is intended that ECTS credits help them to be realistic about the necessary workload and to choose learning, teaching and assessment strategies wisely (European Commision 2009). The ECTS system is implemented in Romania and the Law of Education provides the following definition for this type of credits: "the amount of directed and independent intellectual work required for the student's individual completion of a course unit within an academic study programme, complemented by validation of learning outcomes" (Article 148). Looking at the law, one can see 
that the amount of intellectual work equivalent to an ECTS credit point is not quantified. However, a set of regulations is imposed by the Education Law regarding the number of ECTS in a more general framework:

(2) The individual intellectual work of a student cannot be lower than that corresponding to an annual number of 60 transferable study credits.

(3) The minimum number of credits needed to pass the academic year is established by the university senate.

(4) The duration of the Bachelor and Master academic study programmes, by areas of specialization, shall be proposed by the Ministry of Education, Youth and Sport and approved through Government decision.

(5) The total cumulated duration of the Bachelor and Master academic cycles of studies corresponds to obtaining at least 300 transferable study credits.

(6) The number of transferable study credits for the doctoral cycle of studies is determined by each university, depending on scientific or artistic field.

In accordance with the Education Law, art. 148, the ECTS system should be implemented by taking into account the amount of work that the student must perform in order to receive the credits and reach the learning outcomes quantified by the credits earned. The ECTS credits should help both to quantify the acquired knowledge, competencies and abilities, and to facilitate mobility. In another words, credits should have both a transfer and an accumulation function. The number of gained credits represents a criterion for promotion from one cycle to another and from one academic year to another. There are additional academic filters for transition from one cycle to another, according to the decisions of universities.

No studies have been identified to confirm the efficiency and comparability of the ECTS in Romanian universities. There seem to be no published studies that look at the relationship between the allocation of ECTS credits, learning outcomes, and student workload either. The IEP reports do not tackle in particular the subject of ECTS implementation in Romania, but some references have been found regarding this subject in six university reports. The main conclusion is that, even if universities have been implementing the ECTS for more than 10 years, this process was mostly superficial and formalistic, rather than representing a real reform, which would have encompassed linking ECTS credits with student workload and learning outcomes. Inconsistencies were found between ECTS and professions governed by Professional Qualifications Directive 2005/36/EC in one university. One recommendation with clear reference to the ECTS system was to "review students' workloads and ECTS to ensure that workloads are manageable".

\subsection{Looking at the SCL in the Context of Teaching Quality of Teaching}

ARACIS is the independent institution responsible for quality assurance in higher education at national level. The standards upon which ARACIS assesses each institution and study programme have a great impact on institutional policies, as 
well as on their strategic behaviour. We have analysed the ARACIS methodology to see whether national quality assurance policies promote SCL and, if this is the case, they follow the Bologna Process commitments regarding SCL.

The ARACIS methodology includes an indicator named "student-centred learning methods." In this case, the minimum required standard (mandatory for each institution) is detailed to include the following:

- "The main responsibility of the academic staff is to design student-centred learning methods and environments, with less emphasis on the traditional responsibility of solely transmitting information;

- The relationship between student and academic staff is one of partnership;

- Learning outcomes are explained and discussed with students in terms of their relevance to their development;

- Academic staff members use new technology resources and auxiliary materials, from the blackboard to flipchart and video projector;" (ARACIS, 2006)

The other standards represent guidelines for universities and are not mandatory:

- "Academic staff members are specially trained in teaching and/or they meet up in discussion groups to discuss teaching methodology; The trainings also include: teaching skills, experience in counselling, monitoring and facilitating the learning process;

- There is an on-going activity of identification, development, testing, implementation and evaluation of effective learning techniques;

- Study programmes are integrated with trainings, placement and internship and with the involvement of the students in research projects;

- The teaching methods includes asking questions in the classroom, short presentations, demonstration experiments;

- The teaching strategy also takes into account the needs of disabled students.

- The institution creates learning environments and experiences that lead students to discover and create knowledge themselves." (ARACIS, 2006)

It is evident from the quotes above that the national quality assurance methodology explicitly includes SCL and that its provisions are in line with the Bologna Process promoted policies. On the other hand, it is difficult to assess the real impact of these provisions in the ARACIS methodology.

References to quality assurance procedures related to teaching were identified in the IEP evaluation reports. In eight out of 27 universities no quality assurance procedures for teaching were found or no significant effort was identified in this direction. Systematic efforts to secure and develop quality teaching were identified in only two universities. The main recommendation in this field was that Quality Assurance Departments should play a more central role in the reporting loop on the quality of teaching and learning. 


\subsubsection{Innovative Teaching Methods or Learning Centred Teaching}

Distinctions are drawn in the specialised literature among different kinds of learning, such as 'understanding', 'factual knowledge' and 'skills', but also among different kinds of learners, such as 'holist' and 'serialist' learners, 'visualizers', 'verbalizers' and'doers', so that teaching methods can be matched to them. Learning-centred teaching involves adopting different teaching methods, where they are appropriate, adapting them to the needs of each student instead of following a one-size-fit-all instrument (Sparkes 1999).

In the context of SCL, the role of teachers becomes as important as it can get, given that teachers have to identify how they can help students to acquire the intended learning outcomes and benefit to the fullest from a specific learning experience (Alexander and Murphy 1998). The main function of teaching is often understood in terms of enhancing effective learning and empowering the student to become responsible for her/his learning process. Good teaching involves, among others, matching teaching methods to students' chosen learning goals, while also catering for students' different preferred learning styles. 'Learning-centred teaching' is an organized way of teaching and learning, which embraces student-centred learning, active and problem-based learning and the use of IT, as well as instruction and demonstration by a teacher, wherever they are appropriate (Sparkes 1999). It identifies where 'the sage on the stage' is a valid teaching technique and where 'the guide on the side' may be more appropriate. It is generally believed that studentcentred teaching allows students to take on more responsibility for deciding what and how to learn so that they can play an active role in their education, thereby achieving higher-level learning outcomes, such as knowledge application and creation. Siding with the student-centred camp, constructivist teaching is an alternative to the conventional teacher-centred teaching method (Yuen and Hau 2006).

For the purpose of the present study we have analysed the implementation in Romania of the particular commitment within the Bologna Process also for the specific areas of development of and focus on innovative teaching methods. When talking about "innovative teaching methods" we mainly consider the references from the Bologna Process which include: involving students as active participants in their own learning process, creating a supportive and inspiring working and learning environment, empowering students to develop intellectual independence, personal self-assurance alongside disciplinary knowledge and skills, ability to assess situations and critical thinking.

To be able to implement innovative teaching methods, well-prepared and motivated teaching staff is needed, and an adequate number of academic staff members is necessary. According to the data provided by the National Institute of Statistics (NIS), at the beginning of the academic year 2010-2011 the total number of students and the number of academic staff members in Romanian higher education were as follows (Table 1):

At the beginning of the academic year 2011/2012, the average ratio of academic staff members to students was about $1 / 33$ (public universities and private universities). There are significant difference between public universities and private 


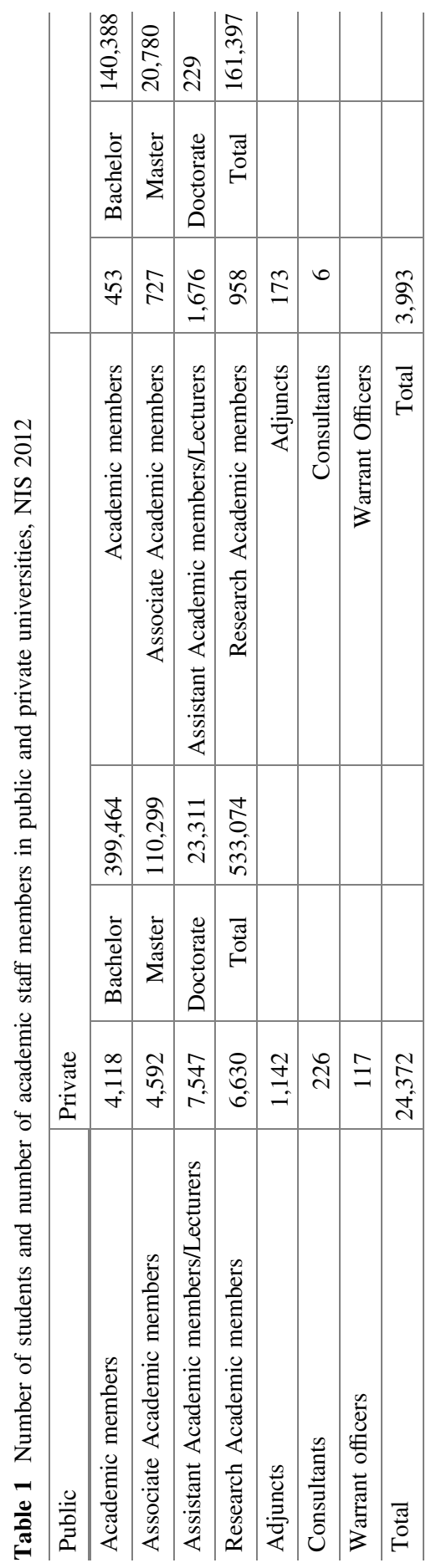


universities. At the beginning of the academic year 2011/2012, the average ratio of academic members to students was:

- $1 / 22$ in state universities;

- $1 / 40$ in private universities.

The analysis based on the IEP evaluation reports indicates that the main issue regarding the teaching staff identified in 18 universities is the lack of incentives and instruments for both developing teaching competences, and motivating and fostering innovation in teaching. The existent universities structures (e.g. the departments for training of teaching staff) do not possess the necessary expertise and resources for teacher training, especially in innovative methods, or for implementing Bologna desiderata in teaching and learning more generally, such as learning outcomes-based teaching and assessment, and student-centred learning. For 12 universities the main recommendation was that teacher training should be made available to the teaching staff and that mechanisms for sharing good practice in teaching should be put in place. Also, the IEP evaluation reports noted that there is an imbalance between the multiple rewards given for excellence research, on one side, and the lack of rewards for innovation and excellence in teaching, on the other. This situation is reflected, among others, in the processes of hiring staff and promotion of teachers. A recommendation made for eight universities by the IEP review panels was to develop instruments and methods of rewarding teaching performance. They could include: using initiatives like "the best teacher of the year", setting up a University Learning and Teaching Enhancement Forum, establishing a Centre for Teaching and Learning (CTL), developing a system of awards and rewards both for individuals (teachers, researchers and students) and academic units that demonstrate excellence in teaching.

At a more general level, an important conclusion emerging from the analysis of the institutional reports is that a certain level of conflict can be seen between research and teaching in the Romanian universities, with two distinct aspects. On one hand there is a situation in which many teachers concentrate more, or mainly, on research (especially young teachers), while neglecting the teaching dimension of their activity. On the other hand, in some cases the teaching workload is so heavy that it leaves little room for research activity.

Other issues related to teaching staff mentioned in the reports are: significant constraints on universities resulting from national regulations, especially regarding the recruitment and promotion of academic staff; salary incentives can be awarded to recognise excellent performance in research, but no teaching excellence or innovation in teaching. The current follow-up of the performance evaluation of the academic staff is mainly based on person-to-person discussions and is not backed by any resources that would recognize and stimulate performance in teaching. The current method of funding for teachers, based on contact hours, has a disproportionate influence on curriculum design and may be a disincentive to curriculum reform.

What is also important in order to provide a supportive learning environment is that classrooms are properly equipped. From this perspective, analysing the data 
obtained in the classification of universities, it is noteworthy that $33 \%$ of university classrooms in Romania are equipped with a video projector, $70 \%$ have at least one $\mathrm{PC}$ and $53 \%$ have wireless internet access.

Out of 27 reports IEP reports, 12 include clear mentions regarding teaching methods. In this regard, in ten universities the main conclusion was that the teaching methods remain mainly traditional. In only two universities an innovative approach to teaching was identified.

The main issues identified in the institutions with a traditional teaching methods were: some members of academic staff appear to have outdated approaches to learning, teaching and assessment; often professors are self-centred in the sense that their teaching is based on the need to justify teacher contact time rather than on the learning needs of students; the presence of one-way lecturing, involving the lack of interactivity in classes and making student feel that courses are irrelevant and outdated. In these cases the main recommendation was to move away from traditional approaches and to adopt more learner-centred pedagogies across all disciplines, together with developing innovative learning methods, like case studies, case competitions, simulation exercises, business games, criterion-referenced assessment techniques, use of technology or greater prominence to pedagogical innovativeness and effectiveness.

One example of good practice regarding the use of technology as a means to promote innovative teaching was identified: the development and use of e-platforms for teaching. Although there are many universities using this tool in their day-to-day activities, in many cases it appears to be an instrument used rather for administrative reasons or, at most, as channels of information and communication, rather than for learning properly. One university was identified which has succeeded in implementing a platform that includes direct access to academic and research related material pertinent to the students' specific activities and specialities, student evaluations, and efficient teacher-student communication instruments.

\subsection{Stakeholders Perception Regarding SCL Implementation}

According to the National Alliance of Student Organizations in Romania (ANOSR) study concerning students' views on the implementation of the Bologna Process (2009), involving 23 universities, "in only $15 \%$ of universities the student organisations consider that the academic staff have adapted to the needs of students." With regard to the evaluation of the academic staff by students, the same study concluded: 'In over $61 \%$ of universities, students' feedback is not taken into consideration, and no measures are taken as a follow-up to the results. Only in $22 \%$ of universities the feedback is taken into account in the educational activity". Overall, according to the same study, the perception of student organizations regarding the implementation of SCL in Romanian universities is that: "Even though at the national level there is a tendency to adapt teaching methods to 
students' needs, this phenomenon is in its infancy, therefore we shall categorize the concept of student-centred learning as being poorly implemented." (ANOSR 2009).

The "Quality Barometer" (ARACIS 2010), a study released periodically by ARACIS, concluded in its 2010 issue that: "We have a rather self-centred university preoccupied by its own financial survival, students are the utmost important from a quantitative perspective, as carriers of financial resources". This study further details that:

- Romanian higher education is student-centred at a formal level, through the university mission statements and charters, but this formal claim is not supported by adequate learning outcomes of students and graduates;

- There is a difference between the students' expectations regarding the outcomes of higher education and what universities can offer in terms of skills' development.

In order to promote student-centred education in universities and to help shape an SCL culture at the national level, ANOSR organizes the annual "Gala of the Bologna Professor," a project in which students evaluate and acknowledge academic staff members that are promoters of student-centred education. The methodology for assessment is based on indicators resulting from the operationalization of the student-centred learning concept from a student perspective, and includes:

- Learner-focused teaching methods (including the active participation of students),

- The outcomes of the course are focused on gaining specific competences, not on unidirectional information transmission,

- The use of technology within teaching and learning methods (via emails, group discussions, open electronic resources, webinars etc.),

- A collaborative teacher-student relationship.

This initiative represents a rare incentive for Romanian teachers to enhance their pedagogical methods and be more innovative and responsive to the profile of current learners. In the 2007-2012 timeframe, 400 teachers from all over the country have been awarded the 'Bologna Teacher' label and in this way a "community of practice" started to be formed.

\section{Conclusions}

Romania signed the Bologna Declaration 15 years ago and is implementing the Bologna principles and action lines ever since. Nevertheless, it appears that a limited awareness or partial understanding of the Bologna principles by the academic communities is found in the majority of universities. This appears to be the case with all core commitments within the Bologna Process, including the implementation of the ECTS system or of learning outcomes. SCL was only recently 
introduced in the Bologna vocabulary and mentioned in the Bologna Process communiqués (the first attempt being made only in 2009). SCL is used as an umbrella concept at the national and institutional levels, under which various unrelated domestic interests are being gathered.

Even though the SCL concept is not operationalized in the national law on education, the national procedures for quality assurance do provide clear guidelines for SCL implementation. Yet, when analysing institutional behaviour, we found that there is no common understanding of the concept, and no consistent implementation. The main policy rationales for SCL do not appear to be internalized at institutional level.

The understanding of the SCL concept is diverse within and across different categories of stakeholders. At institutional level, this understanding includes certain aspects that are indeed consistent with the model promoted by the Bologna Process documents and reflecting "Bologna commitments" (for example aspects regarding new teaching methods or new approaches to quality of teaching). At the same time, under the label of "Bologna reforms", this understanding also includes aspects that are exterior or only collateral to the Bologna promoted model (such as the involvement of students in research activities or employing students in the university). The inclusion within the SCL legitimation frame of issues and aspects that are clearly unrelated or lack a significant relationship with SCL indicate the lack of basic common understanding of what SCL means in the Romanian context.

SCL policy setting and implementation in Romanian universities are still at the beginning. Some universities are more advanced than others. We have identified universities with no declared approach to SCL, universities with some elements of SCL, and universities with real commitments and doing real work towards SCL. The fact that only $41 \%$ from the institutions (considered for the purpose of this study) do not have a formal institutional approach to SCL suggests that there is a need for further policy development in this area, as well as for public debates on what is understood and assumed by the concept, and on what would be useful to do in practice in this area, beyond the formal commitments as part of the Bologna Process. In fact, the Bologna Process commitments with regard to SCL should represent a good opportunity for a serious deliberation at national and institutional level about the virtues, and perhaps limitations as well, of SCL.

Looking at the implementation of a learning outcomes approach as an essential part of SCL, we can conclude that due to national regulations (included in the National Qualification Framework and the quality assurance procedures), learning outcomes started to be used in the description of study programmes. This use appears to be rather formal for the time being. Learning outcomes are not internalized as core elements along the entire teaching and learning process, including initiation, design, operation, student assessment, and quality assurance of study programmes. Significant further development appears necessary, in particular, in the area of learning outcomes assessment.

The present study confirmed two other important problematic aspects, already acknowledged by other researchers, policy makers, university leaders and student representatives: the lack of focus on soft skills development and assessment, and on 
students practice. The tendency to develop and assess subject-specific knowledge, at the expense of transversal or soft skills or the insufficient opportunities for internships represent issues that require a coherent national and institutional strategic approach for identifying policy solutions.

Regarding the ECTS system, after several years of implementation in Romanian universities, there is still no data available regarding the correlation of ECTS with student workloads or learning outcomes.

Looking at the matter of innovative teaching methods, and more generally at the matter of developing supportive and inspiring learning environments for students, we conclude that there is a lack of incentives and instruments for teacher training, mainly due to the lack of university expertise and resources in this area.

A certain level of conflict appears to be in place between teaching and research. This is due to several factors, including high teaching workloads, but also due to the insufficient number of teaching staff (at national level the ratio of teachers to students appears to be $1 / 33$ in state universities and 1/40 in private universities). The lack of recognition for good teaching and, more generally, the absence of incentives for good teaching is also a factor.

As a final conclusion, based on the analysis of the IEP reports, of the strategic documents of universities and of national perception studies, it appears that approximately $40 \%$ of Romanian universities express no formal commitment to introduce a student centred learning approach. Academic communities do not appear to be convinced of the usefulness or appropriateness of moving towards SCL in the Romanian context. In addition, even though $60 \%$ of universities did choose to include SCL in their strategic approach, at least at formal level, many universities "uploaded" into the concept diverse unrelated domestic objectives, while excluding essential components, such as focusing on learning outcomes, pedagogies reforms or embedding indicators referring to the teaching process within quality assurance procedures.

Open Access This chapter is distributed under the terms of the Creative Commons Attribution Noncommercial License, which permits any noncommercial use, distribution, and reproduction in any medium, provided the original author(s) and source are credited.

\section{References}

Adelman, C. (2009). The Bologna Process for U.S. Eyes: re-learning higher education in the age of convergence. Washington, DC: Institute for Higher Education Policy.

Alexander, P., \& Murphy, P. (1998). The research base for APA's learner-centered psychological principles. In N. Lambert \& B. McCombs (Eds.), How students learn (pp. 25-60). Washington, DC: American Psychological Association.

ANOSR. (2009). Implementarea Procesului Bologna în România:Perspectiva studenţilor. Bucuresti: Alianta Nationala a Organizatiilor Studentesti din Romania.

ARACIS. (2010). Barometrul Calităţii: Starea calităţii în învăţământul superior din România. Bucuresti: Agenția Română de Asigurare a Calităţii în Învăţământul Superior. 
Communique of the meeting of European Ministers in charge of Higher Education. (2012). Making the Most of Our Potential:Consolidating the European Higher Education Area. Bucharest.

Communiqué of the meeting of European Ministers in charge of Higher Education. (2009). The Bologna Process 2020 -The European Higher Education Area in the new decade. Leuven and Louvain-la-Neuv.

Corbett, A. (2006). Higher Education as a Form of European Integration: how novel is the Bologna Process? ARENA working paper series, 15. Centre for European Studies, University of Oslo, Oslo, Norway.

Corbett, A. (2003). Ideas, institutions and policy entrepreneurs: towards a new history of higher education in the European Community. European Journal of Education, 38(3), 315-330.

Corbett, A. (2005). Universities and the Europe of knowledge: ideas, institutions and policy entrepreneurship in European Community higher education policy. London: Palgrave Macmillan .

Ecclestone, K. (1995). Learning outcomes. Sheffield: Centre for Further and Higher Education.

ESU. (2010). Student-Centred Learning Toolkit for students, staff and higher education institutions. Brussels: European Students' Union.

European Commision. (2009). ECTS users' guide. Luxembourg: Office for Official Publications of the European Communities.

Haskel, B. (2009). Weak process, strong results: Cooperation in European Higher Education. (T. I. A., Ed.) Innovative Governance, pp. 273-287.

Lea, S. S. (2003). Higher education students' attitudes student-centred learning: Beyond educational Bulimia. Studies in Higher Education, 28(3), 321-334.

Reinalda, B. (2008). The ongoing bologna process and political science. European Political Science 7(3), 382-393.

Sparkes, J. J. (1999). Learning-centred teaching. European Journal of Engineering Education, 24 (2), 183-188.

Trondal, J. (2002). Europeanisation of Research and Higher Education Policies: some reflections. European Integration Online Papers, 6 (2).

UEFISCDI. (2013). Reflectarea angajamentelor Romaniei in cadrul Spatiului European al Invatamantului Superior (EHEA) in context national. Bucuresti: Unitatea Executiva pentru Finantarea Invatamantului Superior a Cercetarii, Dezvoltarii si Inovarii.

Van Damme, D. (2009). The search for transparency: Convergence and diversity in the Bologna process. In F. van Vught (Ed.), Mapping the higher education landscape. Towards a European classification on higher education (pp. 39-55). Houten: Springer.

Veiga, A. (2005). Europeanization of higher education area: towards a framework of analysis.

Watson, P. (2002). The role and integration of learning outcomes into the educational process. Active Learning in Higher Education, 3(3), 205-219.

Yuen, K.-M., \& Hau, K.-T. (2006). Constructivist teaching and teacher-centred teaching: a comparison of students' learning in a university course. Innovations in Education and Teaching International, 43(3), 279-290.

\section{Data Used}

Data from the National Institute for Statistics (NIS), "TEMPO online" data base, extracted on September 2013, the "Statistical annual reports on higher education" and NIS communication from the official website.

Data from the data collection process conducted in 2011 in order to assess and classify universities and study programs http://uefiscdi.gov.ro/articole/2535/Clasificare-universitati-si-ierarhizareprograme-de-studii.html. 


\section{Legal Documents}

National Education Law no. 1/2011.

ARACIS. (2006). External evaluation methodology, standards, reference standards and performance indicators.

\section{Online Resources}

"Higher Education Evidence Based Policy Making: a necessary premise for progress in Romania" project implemented by the Executive Agency for Higher Education, Innovation and Development Funding (UEFISCDI) - http://www.politici-edu.ro/?lang=en. 